\title{
TOX Gene
}

National Cancer Institute

\section{Source}

National Cancer Institute. TOX Gene. NCI Thesaurus. Code C147946.

This gene plays a role in $\mathrm{T}$-cell development. 